\title{
MEMBATIK UNTUK ANGGOTA MAJELIS TAKLIM SALSABILA AL BAROKAH DI LEBAK JAKARTA SELATAN
}

\author{
Mochamad Fauzie, Umi Kholisya, Catur Sunu Wijayanto \\ Desain Komunikasi Visual, Fakultas Bahasa dan Seni, \\ Universitas Indraprasta PGRI \\ ahmadantawirya@yahoo.co.id,umi_history@yahoo.com
}

\begin{abstract}
Abstrak
Untuk melestarikan batik perlu dilakukan inventarisasi motif ragam hias, pewarisan keterampilan membatik dan penanaman apresiasi. Sasarannya adalah calon pengrajin dan kepada masyarakat yang akan menjadi tempat tumbuh dan berkembangnya kesenian tersebut. Tahap pelestarian batik tersebut diterapkan kepada anggota majelis taklim Salsabila Al Barokah di Kampung Lebak, Jakarta Selatan dengan mempertimbangkan kebutuhan mitra akan keterampilan memproduksi komoditi, dihubungkan dengan fakta, bahwa sebagian besar beretnis Betawi dan memiliki pengetahuan yang baik tentang ragam hias Betawi yang dapat diterapkan menjadi komponen utama batik. Metode perlakuannya adalah dengan memberi pengetahuan tentang sejarah singkat dan filosofi batik di Indonesia, meneguhkan dan menambah pengetahuan tentang ragam hias Betawi sebagai komponen batik, dan memberi praktik latihan membatik. Pencapaian yang dihasilkan adalah terjadi peningkatan pengetahuan tentang batik, penguasaan ketrampilan dasar membatik, dan peningkatan penghargaan terhadap batik.
\end{abstract}

Kata kunci: batik, kriya tekstil, Betawi, ragam hias

\begin{abstract}
To preserve batik need to inventory motif of decoration, inherit of batik skill and appreciation planting. The target is the prospective craftsmen and to the community that will be the place to grow and develop the arts. The batik preservation phase is applied to members of the Salsabila Al Barokah assembly in Kampung Lebak, South Jakarta by considering the partner's need for the skills of commodity production, related to the fact that most of them are Betawi ethnic and have a good knowledge of the applicable Betawi ornaments being the main component batik. The method of treatment is to give knowledge about the brief history and philosophy of batik in Indonesia, affirming and adding knowledge about Betawi decoration as batik component, and giving practice of batik training. The resulting achievement is an increase in knowledge about batik, mastery of basic skills of batik, and increased appreciation of batik.
\end{abstract}

Keywords: batik, textile craft, Betawi, decoration

\section{PENDAHULUAN}

Indonesia memiliki hasil-hasil kebudayaan yang kaya dan beragam, yang menjadi bagian dari identitas bangsa dan sekaligus komoditi yang menunjang perekonomian bangsa. Di antara hasil kebudayaan dengan kualifikasi demikian adalah sekelompok karya seni yang disebut seni kriya, yakni karya seni rupa yang dibuat dengan mengandalkan keterampilan tangan untuk memenuhi fungsi pakai dan fungsi keindahan. Di antara produk seni kriya Indonesia yang sudah diakui dunia adalah Batik. Bukti pengakuan dunia 
tersebut adalah ketetapan UNESCO) PBB pada 2009, bahwa batik adalah kain berlukis khas Indonesia yang menjadi warisan budaya dunia non-benda (Republika, 1/04/2012:06).

Batik merupakan cara menghias latar kain melalui teknik celup rintang (Wardhani dan Panggabean, 2004:45). Dikatakan celup rintang karena kain dicelupkan ke cairan warna dalam keadaan sebagian bidangnya dirintang (ditutup). Mengenai bahan yang dipakai untuk merintang, Setiawati (2004:9) menyatakan, bahwa batik adalah gambaran atau hiasan pada kain yang pengerjaannya melalui proses penutupan dengan lilin (malam), yang kemudian dicelup atau diberi warna. Penutupan tersebut dilakukan dengan cara menorehkan malam dengan menggunakan canting. Hiasan yang ditorehkan adalah motif dan pola ragam hias. Sedangkan jenis kain yang lazim dipakai adalah katun yang disebut mori. Mori yang sudah bergaris-garis malam tersebut lalu dicelupkan ke cairan warna. Malam kemudian dilepaskan (dilorod) dari mori dengan cara direbus, sehingga meninggalkan warna dasar. Pencelupan ke cairan warna dapat dilakukan berulangkali sebanyak warna yang dikehendaki. Pewarnaan melalui pencelupan acapkali dikombinasikan dengan teknik colet, yakni mengoleskan pewarna secara langsung dengan memakai kwas (Sudja, 1979: 21).

Batik telah ditemukan pada masa Majapahit, tetapi sejarah dan perkembangannya di Nusantara baru terekam dengan baik sejak masa Kerajaan Mataram Islam (abad ke-17) di Jawa Tengah. Dudung Alie Syahbana menyatakan, sejak era Mataram Islam berbagai kesenian-termasuk ragam hias sebagai komponen batik-mengalami stilasi (penggayaan) bentuk dari bentuk-bentuk pada masa Hindu untuk menghindari penggambaran makhluk bernyawa secara realistik (Republika, 1/4/2012:6).

Sebagai komoditi, batik turut menyumbang pada perjuangan kemerdekaan dengan menjadi alat perjuangan melalui sektor ekonomi. Sampai pertengahan abad ke-20, membatik dan menjual batik merupakan profesi wirausaha yang sangat menggejala di masyarakat di Pulau Jawa, seperti yang ditekuni oleh $\mathrm{KH}$ Ahmad Dahlan dan para pengikutnya di Kampung Kauman, Yogyakarta. Kala itu, batik mampu membangun ekonomi umat, bahkan menjadi sumber pembiayaan pembangunan sekolah dan klinik pengobatan umum. Hal yang sama dilakukan oleh Samanhudi (1868-1956) di Surakarta, dengan mendirikan Sarekat Dagang Islam (SDI) sebagai bentuk koperasi bagi para pedagang batik di Jawa (Suryanegara, 2009:349-367). Memasyarakatnya batik pada masa itu menunjukkan, bahwa keterampilan membatik tidak sukar untuk dikuasai, terlebih mengingat sebagian besar pengikut pertama Ahmad Dahlan bukanlah orang-orang yang terpelajar.

Sejak PBB menetapkan batik sebagai warisan budaya dunia, penghargaan masyarakat Indonesia pada batik seperti bangkit kembali. Namun sedemikian jauh, pengetahuan perihal batik pada kebanyakan masyarakat masih sangat minim. Batik yang dimaksudkan UNESCO adalah batik tradisional (yang dikerjakan secara manual dengan menggunakan canting atau cap, atau kombinasi keduanya), tetapi dalam pengetahuan sebagaian besar masyarakat kita, "batik" menunjuk bukan pada batik yang sesungguhnya, melainkan pada tekstil bermotif batik atau batik printing. Tambahan lagi, sebagian besar batik serupa ini merupakan barang impor.

Batik diharapkan tetap lestari atau terpelihara sebagai produk seni daerah 
yang menyumbang pada identitas bangsa, dan sekaligus komoditi. Menurut Ajip Rosidi (2010:15-16), untuk melestarikan seni daerah yang harus dilakukan mula-mula adalah membuat inventarisasi produk budaya daerah. Dalam konteks batik sebagai produk budaya, upaya inventarisasi tersebut meliputi motif-motif ragam hias daerah sebagai komponen utama batik. Selanjutnya Rosidi (2010:15) mengatakan, bahwa inventarisasi tersebut akan memudahkan langkah-langkah pelestarian berikutnya, yakni: pewarisan keterampilan berkesenian dan penanaman apresiasi (penghargaan) terhadap berbagai produk seni daerah. Sasarannya adalah calon seniman atau pengrajin dan kepada masyarakat yang akan menjadi tempat tumbuh dan berkembangnya kesenian tersebut.

Dilihat dalam perspektif estetika, inventarisasi produk seni daerah (objek estetis) memungkinkan orang (subjek estetis) untuk berinteraksi dan memperoleh pengalaman estetis, sedangkan pengalaman membuat karya seni daerah memberi pengalaman artistik. Kedua pengalaman tersebut akan meningkatkan penghargaan subjek estetis terhadap objek estetis. Di antara keduanya terdapat nilai estetis, yakni pengetahuan tentang batik terkait parameter estetis batik sebagai seni kerajinan tekstil dengan segala keteraturan (order) terkait dengan alat, media, teknik, proses, fungsi pakai dan fungsi etetisnya. Kelindan antara subjek, objek dan nilai estetis dinyatakan Deni Junaedi (2016) sebagai proses estetis. Maka, diletakkan dalam konteks pelestarian batik, terdapat tiga target pengembangan, yakni: (1) pengetahuan tentang batik, (2) pengalaman berinteraksi dengan batik atau komponennya, dan (3) keterampilan membatik.

\section{Permasalahan Mitra}

Majelis Taklim Salsabila Al Barokah merupakan organisasi informal masyarakat, berbentuk kelompok pengajian muslimah. Majelis ini dibina oleh Ibu Tamronah dan diketuai oleh Ibu Nur Hikmah. Agenda tetapnya adalah setiap Kamis mengadakan tilawah Al Qur'an, tahsin, fiqih, mentoring keputrian, belajar pidato dan membaca sholawat/ rawi. Kegiatan-kegiatan tersebut diadakan atau berpusat di kediaman Annisa Albi di Jl. Lebak Sari No. 64, RT 10 RW 05, Kelurahan Tanjung Barat, Jakarta Selatan. Alamat ini berada dalam sebuah kampung kecil yang dikenal dengan nama Kampung Lebak.

Anggota majelis taklim tersebut terdiri dari para ibu rumah tangga berusia 30 sampai 50 tahun. Jumlah ibu rumah tangga yang aktif menghadiri pengajian mencapai lebih dari 30 orang. Mereka sangat bersemangat belajar agama. Melalui wawancara terungkap, bahwa hampir seluruhnya beretnis Betawi. Diketahui pula, mereka memiliki pengetahuan yang baik tentang aneka motif ragam hias etnis Betawi. Pengetahuan demikian merupakan modal yang diperlukan dalam membuat batik, mengingat ragam hias adalah komponen utama batik. Permasalahan mitra adalah mereka ingin membantu suami mereka untuk meningkatkan pendapatan rumah tangga, tetapi tidak memiliki keterampilan untuk memproduksi barang dagangan.

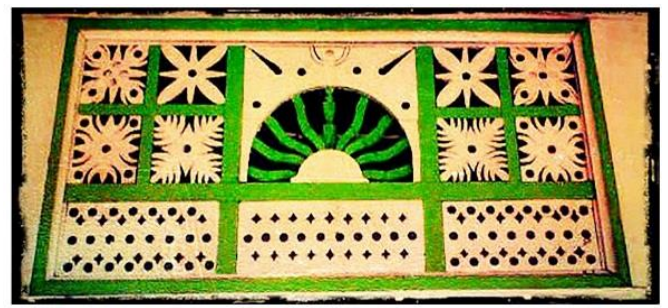

Gambar 1. Ragam hias Betawi sebagai elemen arsitektur rumah adat Betawi (Sumber: http://cintebetawi.com/2013/07/16/ornamenornamen-pada-rumah-betawi/, diunduh pada 10 Maret 2017) 


\section{Solusi yang Ditawarkan}

Mempertimbangkan pengenalan mitra yang cukup baik tentang aneka ragam hias Betawi, maka solusi yang ditawarkan adalah menguasai keterampilan dasar untuk menghasilkan batik dengan motif ragam hias Betawi. Bentuk solusi atau pemecahan masalah tersebut adalah: (1) Memberi visi untuk turut melestarikan ragam hias Betawi dan batik sebagai warisan budaya bangsa, (2) Memberi penguatan pengetahuan tentang aneka ragam hias Betawi sebagai bentuk inventarisasi motif batik Betawi, (3) Memberi pelatihan dasar membatik untuk memproduksi batik bermotif ragam hias Betawi yang memiliki fungsi pakai dan fungsi keindahan. Diharapkan akan diikuti dengan fungsi komoditi (memiliki nilai jual) untuk meningkatkan taraf perekonomian keluarga.

\section{Target dan Luaran}

Target dalam arti sasaran pengabdian masyarakat adalah $30 \mathrm{ibu}$ rumah tangga anggota Majelis Taklim Salsabila Al Barokah. Dihubungkan dengan target pelestarian batik, mereka ini dapat dipandang sebagai calon pengrajin dan atau masyarakat yang akan menjadi tempat tumbuh dan berkembangnya batik Betawi.

Target dalam arti capaian (hasil) yang dicanangkan dalam pengabdian masyarakat ini, bahwa setelah mengikuti pelatihan membatik, peserta diharapkan mampu: (1) Menjelaskan hakikat dan sejarah batik; (2) Mengenali pelbagai motif ragam hias Betawi sebagai komponen batik Betawi; (3) Membuat batik bermotif ragam hias Betawi yang memiliki fungsi pakai, fungsi keindahan (hias), dan fungsi komoditi.Adapun luaran Pengabdian Masyarakat ini adalah: (1) 30 helai batik bermotif ragam hias Betawi dengan fungsi pakai taplak meja, dan fungsi sebagai hiasan, dan; (2) artikel untuk jurnal perguruan tinggi selingkung PGRI.

\section{METODE PELAKSANAAN}

Waktu kegiatan mulai dari perencanaan, persiapan, pelaksanaan, hingga penyusunan laporan berlangsung mulai pekan terakhir Maret sampai dengan akhir September 2017. Lokasi kegiatan berlangsung di kediaman Annisa Albi, S.Pd. di Jalan Lebak Sari Nomor 64, RT 10 RW 05, Tanjung Barat, Jakarta Selatan.

Metode pelaksanaan terdiri dari enam tahap, yaitu: (1) Komunikasi: pembicaraan dengan mitra terkait dengan hakikat pengabdian masyarakat sebagai bagian dari pelaksanaan Tri Darma Perguruan Tinggi. Dalam pada ini disampaikan tentang tujuan dan rencana pengabdian masyarakat, dan penegasan bahwa kegiatan akan dilakukan oleh dosen-dosen yang kapabel dan kompeten dengan materi terkait. Tahap ini berkelindan dengan tahap observasi dengan keluaran berupa surat kesediaan mitra untuk menerima kegiatan pengabdian masyarakat; (2) Observasi dan legalisasi: pendataan tentang kondisi mitra, mengidentifikasi permasalahan mitra, merumuskan solusi dan menyusun proposal; (3) Strategi, menunjuk pada penyusunan: materi pelatihan dan teknik penyampaian, pembagian tugas, dan jadwal kegiatan; (4) Eksekusi, menunjuk pada pelaksanaan puncak pelatihan membatik; (5) Evaluasi: mengkaji kegiatan yang telah dilaksanakan untuk mengetahui tingkat keberhasilan dikaitkan dengan ketepatan jadwal, proses dan hasil belajar target dan mutu keluaran; (6) Reportasi, ialah penyusunan laporan untuk MONEV dan laporan akhir.

Adapun mengenai materi pelatihan, sebagaimana di sebut pada poin 3 , urutannya adalah sebagai berikut: (1) Pengetahuan tentang sejarah singkat dan 
filosofi batik di Indonesia, disampaikan oleh Umi Kholisya, ditunjang media audio-visual (proyektor dan komputer), (2) Pengetahuan tentang ragam hias Betawi untuk Batik, disampaikan oleh Catur Sunu Wijayanto ditunjang oleh media audio-visual (proyektor dan komputer), (3) Praktik membatik, dipandu oleh Mochamad Fauzie dengan dibantu lima mahasiswa. Sebanyak 30 peserta dibagi dalam enam kelompok, sehingga setiap kelompok beranggota 5 orang dan didampingi satu mahasiswa. Setiap kelompok mendapatkan satu set kompor-wajan-lilin (malam), 3 buah canting, dan bekerja mengikuti tahaptahap sebagai berikut:

Persiapan (Pemensilan). Pada tahap ini, setiap peserta mendapatkan satu pensil 2B dan satu helai kain blacu (mori blaco; tekstil jenis mori kualitas terendah yang lazim digunakan untuk latihan membatik) berukuran $50 \mathrm{~cm} \mathrm{x}$ $50 \mathrm{~cm}$. Pada tahap ini, kain digambari dengan motif batik Betawi yang dikehendaki. Untuk mempercepat pelatihan, kain-kain ini telah diberi gambar oleh tim pelatih, sehingga peserta tinggal menambah atau memperinci sesuai selera masing-masing

Pemalaman. Tahap ini mengharuskan tiap kelompok merebus lilin/ malam sehingga mencair. Menggunakan canting, tiap peserta pelatihan menorehkan malam cair ini pada kain dengan mengikuti motif pensil yang sudah dibuat

Pencelupan. Dalam tahap ini, kain yang sudah diberi motif dengan lilin/malam, dicelupkan ke dalam tiga ember cairan secara berurutan. Ember pertama berisi larutan Napthol, TRO dan soda kostik dalam 1 liter air. Larutan ini dibuat dengan lebih dulu mencampurkan ketiga jenis senyawa kimia tersebut dengan air panas. Ember dua, berisi larutan garam warna dengan satu liter air dingin. Sedangkan ember tiga berisi air tawar dingin semata, dengan fungsi sebagai penetral. Kain dicelupkan ke ember satu hingga meresap, ditiriskan barang 2-3 menit, lalu dicelupkan ke ember dua. Ketika dicelupkan di ember 2 inilah, warna akan keluar. Sekali lagi, peserta harus memastikan bahwa cairan telah meresap ke kain, kemudian ditiriskan sejenak, dan dicelupkan ke ember tiga. Jika warna yang dihasilkan dinilai kurang tajam, pencelupan dapat diulangi lagi dengan urutan yang sama sampai 3-4 putaran

Pelorodan. Bagian ini menunjuk pada usaha melunturkan lilin dari kain. Dengan menggunakan kompor dan wajan yang sama, tiap kelompok diminta merebus air dengan diberi 2-3 gram soda abu. Saat air sedang mendidih, kain hasil pencelupan direbus selama 4-5 menit. Tahap ini diakhiri dan ditandai dengan lunturnya lilin dari kain, sehingga bagian yang berlilin akan meninggalkan warna dasar kain, sedangkan bagian yang tidak diberi lilin akan berwarna. Pengabdian kepada Masyarakat dilaksanakan dengan dukungan Lembaga Penelitian dan Pengabdian kepada Masyarakat (LPPM) Universitas Indraprasta PGRI LPPM.

\section{Kualifikasi Tim Pelaksana}

Pelaksanaan kegiatan Pengabdian kepada Masyarakat ini melibatkan beberapa sumber daya manusia yang kapabel dan kompeten dalam bidangnya. Kualifikasi dari anggota Tim Pengabdian kepada Masyarakat meliputi: (1) Memiliki latar belakang keilmuan Seni Rupa dan Desain, khususnya kriya teksil, dalam hal ini adalah Batik, (2) Memiliki pengetahuan tentang sejarah batik, (3) Memiliki pengetahuan tentang ragam hias, khususnya ragam hias Betawi, (4) Menguasai teknik dasar membatik, (5) Memiliki pengalaman memberi pelatihan membatik kepada masyarakat. Tim pengabdian masyarakat ini terdiri dari tiga orang dosen dan 
dibantu oleh enam yang telah lulus mata kuliah gambar etnik (gambar ragam hias) dan telah mendapat latihan keterampilan dasar membatik.

\section{HASIL DAN PEMBAHASAN}

Rangkaian kegiatan pelatihan membatik telah dilaksanakan sejak Maret sampai dengan September 2017, yang berturut-turut terdiri dari: perencanaan, persiapan, pelaksanaan, dan penyusunan laporan. Puncak kegiatan tersebut adalah praktik melatih membatik pada 20 Juli 2017, yang dikuti oleh 30 peserta, dan bertempat di kediaman Annisa Albi, di Jalan Lebak Sari Nomor 64, RT 10 RW 05, Tanjung Barat, Jakarta Selatan.

Praktik membatik didahului dengan tanya-jawab untuk mendapatkan gambaran tentang pengetahuan awal peserta terkait pengertian dan sejarah batik, pelbagai motif ragam hias Betawi, dan keterampilan awal yang dimiliki. Dari tanya-jawab ini diketahui, bahwa: hampir seluruh peserta tidak memahami hakikat batik (tradisional) dan proses pembuatannya; sebagian besar peserta mempunyai pengetahuan yang cukup baik tentang pelbagai ragam hias Betawi, dan; seluruh peserta tidak memiliki pengalaman membatik.

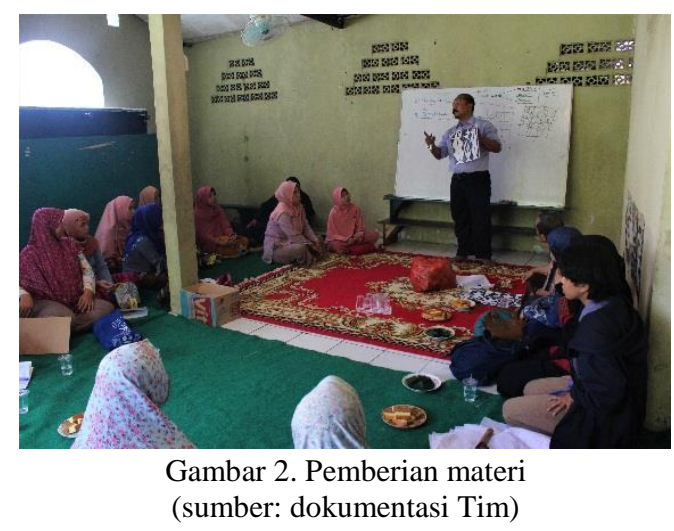

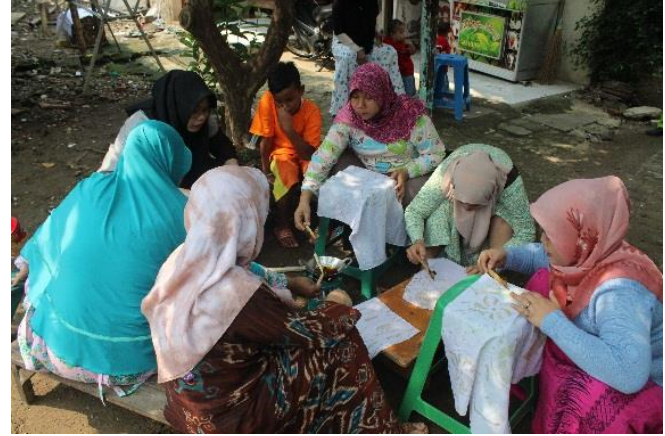

Gambar 3. Praktik membatik tahap pemalaman (sumber: dokumentasi Tim)

Tanya-jawab dilanjutkan dengan pemberian materi teori berupa: sejarah singkat dan filosofi batik di Indonesia, pengetahuan tentang ragam hias Betawi untuk Batik. Sesi terakhir, praktik membatik. Pelatihan membatik dimulai pukul 08.00 WIB dan berakhir sekitar 15.00 WIB, menghasilkan 30 helai batik dengan fungsi keindahan dan fungsi pakai sebagai taplak meja. Ditinjau berdasar kualitas teknik yang dicapai sebagai karya pemula, delapan karya di antaranya tergolong baik, 10 karya sedang, dan sisanya (12 karya) kurang. Kekurangan secara teknik lebih banyak dikarenakan penggunaan canting yang belum terampil, antarai lain ditandai dengan: garis-garis dengan ketebalan yang tidak ajeg, dan bidang (blok) tidak beraturan.

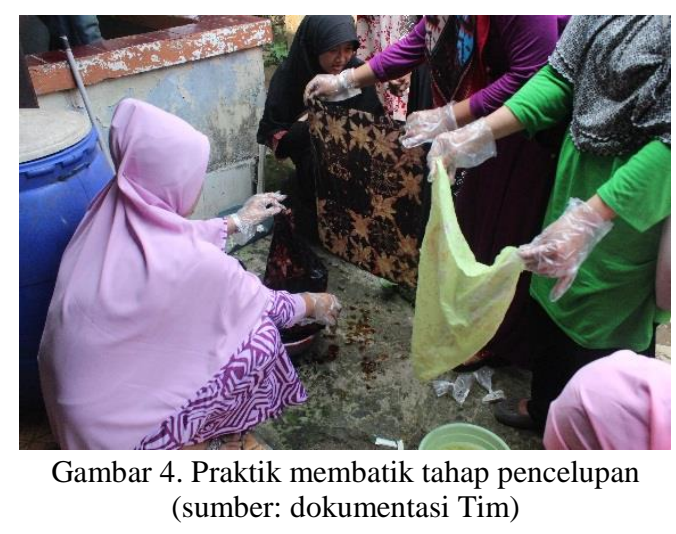

Setelah mengikuti pelatihan membatik, tanya-jawab kembali dilakukan untuk mendapatkan gambaran tentang pencapaian secara kognitif dan afektif. 
Didapat gambaran, sebagian besar peserta mampu menjelaskan hakikat dan sejarah batik dengan benar. Demikian pula mereka mampu mengenali lebih banyak motif ragam hias Betawi sebagai komponen batik Betawi. Pada aspek sikap, sebagian peserta menunjukan penghargaan yang lebih baik terhadap batik, ditandai dengan: keinginan untuk mendapatkan pembinaan lebih lanjut; empati pada pekerjaan membatik sebagai pekerjaan yang memerlukan ketekunan dan ketelitian; dan memaklumi batik sebagai komoditi yang sepantasnya berharga relatif mahal.

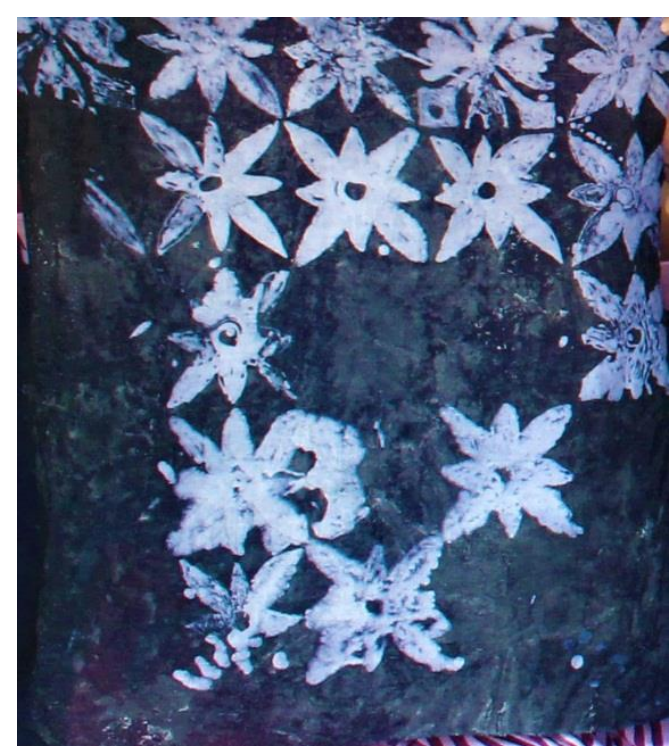

Gambar 5. Karya salah satu peserta dengan kualitas "baik" (Sumber: Dokumentasi Tim)

\section{SIMPULAN}

Pelatihan membatik untuk anggota Majelis Taklim Salsabila Al Barokah di Kampung Lebak, Jakarta Selatan, telah selesai ditunaikan. Puncak pelatihan dilakukan pada 20 Juli 2017, dengan diikuti 30 peserta. Hasil pengabdian masyarakat ini ditandai dengan beberapa pencapaian utama berikut ini:

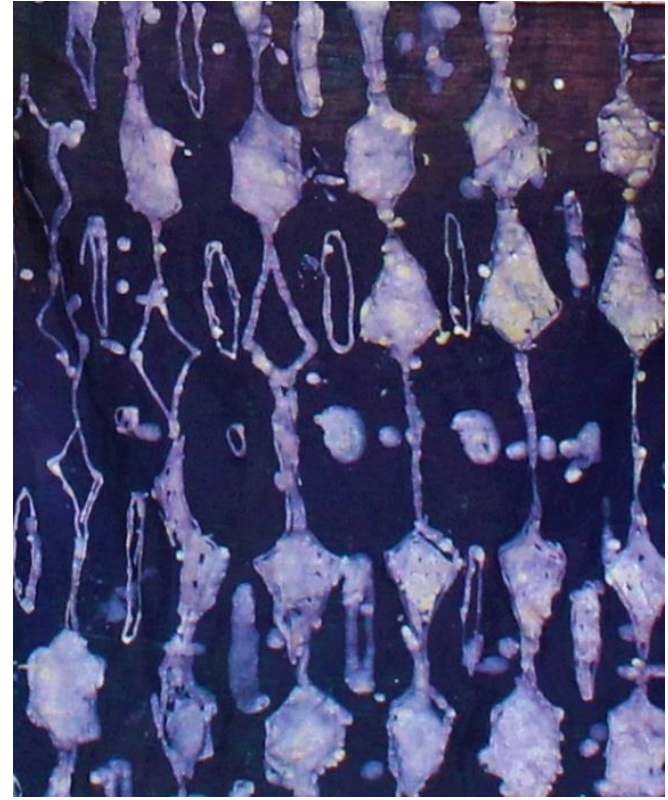

Gambar 6. Karya salah satu peserta dengan kualitas "sedang" (Sumber: Dokumentasi Tim)

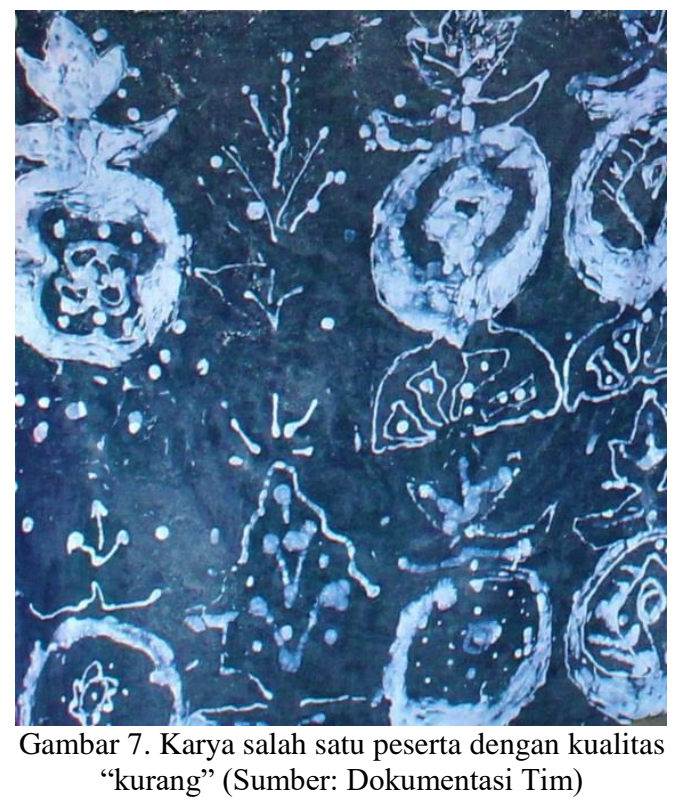

Peningkatan pengetahuan dari sebelum dengan sesudah mendapat pelatihan, meliputi pengetahuan tentang hakikat batik (tradisional), ragam hias Betawi dan proses pembuatan batik. Peningkatan psikomotor dari sebelum dengan sesudah mendapat pelatihan, yakni dari tidak menguasai sama sekali menjadi menguasai keterampilan dasar membatik. Pencapaian ini ditandai dengan telah dihasilkannya 30 helai batik dengan fungsi keindahan dan 
fungsi pakai sebagai taplak meja dengan kualitas teknik yang baik, sedang dan kurang.

Perubahan sikap, bahwa sebagian peserta menunjukan penghargaan yang lebih baik pada batik dengan berkeinginan belajar membatik lebih lanjut, empati pada pengrajin batik dengan mengingat tingkat kesulitan membuat batik, serta pemakluman batik sebagai komoditi yang berharga relatif mahal.

Disarankan agar dilakukan pembinaan keterampilan membatik lebih lanjut, seperti pada aspek teknik dengan memperkenalkan beberapa teknik batik lagi, seperti: cap, colet dan soga. Pengembangan teknik ini dengan sendirinya meniscayakan penggunaan bahan-bahan baru. Di samping itu, pembinaan pada aspek estetika perlu dilakukan juga, terkait dengan fungsifungsi yang beroperasi dalam batik: estetik semata, simbolik, dan naratif. Saran ini dapat direalisasikan melalui kegiatan Pengabdian kepada Masyarakat yang berkelanjutan. Disarankan pula untuk membantu subjek pelatihan dengan pembinaan pada aspek kewirausahaan sehubungan fungsi batik sebagai komoditi yang memerlukan kemampuan pemasaran.

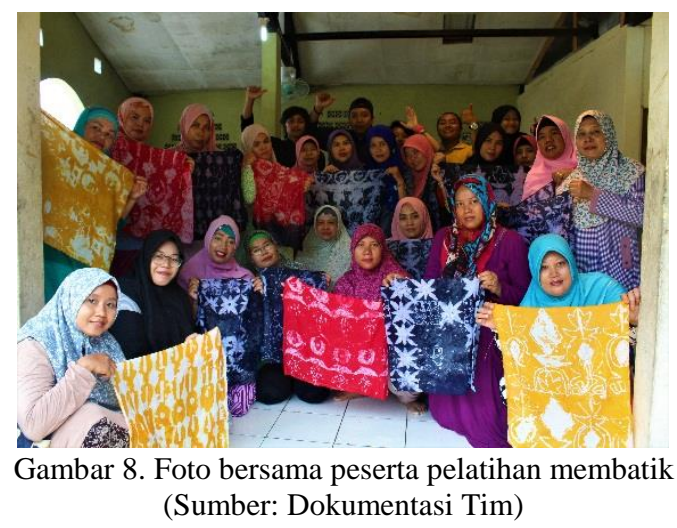

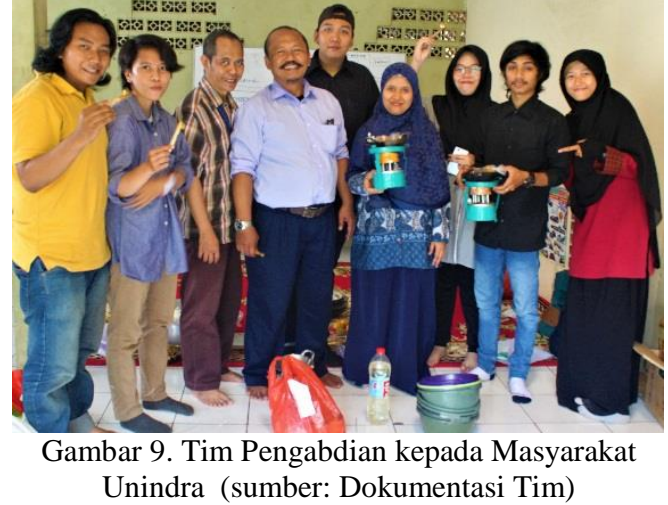

\section{DAFTAR PUSTAKA}

Harun, I. B. dkk. (1991). Rumah Tradisional Betawi. Jakarta: Dinas Kebudayaan DKI Jakarta

Junaedi, D. (2016). Estetika: Jalinan Subjek, Objek dan Nilai. Yogyakarta: ArtCiv,

Rosidi, A. (2010). Masa Depan Budaya Daerah. Jakarta: Dunia Pustaka Jaya

Setiawati, P. (2004). Membatik. Yogyakarta: Absolut

Sudja, W. A. (1979). Proses Pembuatan dan Pewarnaan Batik di Indonesia. Bandung: PT. Karya Nusantara

Suryanegara, A.M. (2009). Api Sejarah. Bandung: Salamadani Pustaka Semesta

Wardhani dan Panggabean. (2004). Tekstil. Jakarta: Lembaga Pendidikan Seni Nusantara

\section{Penerbitan pers}

Republika, Ahad, 1 April 2012

\section{Laman}

http://cintebetawi.com/2013/07/16/orna men-ornamen-pada-rumahbetawi/ (diunduh pada 10 Maret 2017) 